\title{
Nanostructured Mesoporous Titanium Dioxide Thin Film Prepared by Sol-Gel Method for Dye-Sensitized Solar Cell
}

\author{
Yu-Chang Liu, Yun-Fang Lu, Yz-Zhen Zeng, Chi-Hung Liao, \\ Jen-Chieh Chung, and Tsong-Yang Wei
}

Institute of Nuclear Energy Research, AEC, Taoyuan County 32546, Taiwan

Correspondence should be addressed to Yu-Chang Liu, eddyliu@iner.gov.tw

Received 17 February 2011; Accepted 8 April 2011

Academic Editor: Mohamed Sabry Abdel-Mottaleb

Copyright (c) 2011 Yu-Chang Liu et al. This is an open access article distributed under the Creative Commons Attribution License, which permits unrestricted use, distribution, and reproduction in any medium, provided the original work is properly cited.

\begin{abstract}
Titanium dioxide $\left(\mathrm{TiO}_{2}\right)$ paste was prepared by sol-gel and hydrothermal method with various precursors. Nanostructured mesoporous $\mathrm{TiO}_{2}$ thin-film back electrode was fabricated from the nanoparticle colloidal paste, and its performance was compared with that made of commercial P25 $\mathrm{TiO}_{2}$. The best performance was demonstrated by the DSSC having a $16 \mu \mathrm{m}$-thick TTIP-TiO 2 back electrode, which gave a solar energy conversion efficiency of $6.03 \%$. The ability of stong adhesion on ITO conducting glass substrate and the high surface area are considered important characteristics of $\mathrm{TiO}_{2}$ thin film. The results show that a thin film with good adhesion can be made from the prepared colloidal paste as a result of alleviating the possibility of electron transfer loss. One can control the colloidal particle size from sol-gel method. Therefore, by optimizing the preparation conditions, $\mathrm{TiO}_{2}$ paste with nanoparticle and narrow diameter distribution was obtained.
\end{abstract}

\section{Introduction}

Titanium dioxide $\left(\mathrm{TiO}_{2}\right)$ has attracted tremendous attention from researchers worldwide due to its potential applications in environmental protection and energy generation [1]. It has demonstrated unique properties such as high adsorption ability and good photocatalytic activity. Recently, $\mathrm{TiO}_{2}$ has been applied largely in dye-sensitized solar cell (DSSC) due to its nanocrystalline mesopore nature that translates to high surface area for dye adsorption. The adsorbed dye molecules can then be excited by the solar energy to generate electronhole pairs that are subsequently separated and transported within the lattice of $\mathrm{TiO}_{2}$ [2]. Burnside et al. [3] reported a dye-sensitized solar cell that comprises a black-dye-adsorbed $\mathrm{TiO}_{2}$ working electrode, which achieved a high solar energy conversion efficiency $(\eta)$ of $10.4 \%$ [4]. The nanoparticle film is $16 \mu \mathrm{m}$ thick, and the anatase $\mathrm{TiO}_{2}$ was prepared by the hydrolysis of titanium(IV) isopropoxide.

The $\mathrm{TiO}_{2}$ film working electrode is an important part of DSSC. It can be prepared by various methods such as solgel [5-7], chemical vapor deposition (CVD) [8, 9], and sputtering [10-12]. Sol-gel process is a favorable method for preparing $\mathrm{TiO}_{2}$ nanoparticles since the composition, particle size, film thickness, and porosity of $\mathrm{TiO}_{2}$ can be easily controlled by adjusting parameters such as sol concentration, hydrothermal growth temperature, and sintering condition. Hydrolysis of titanium(IV) isopropoxide in acidic solution was performed by Dolmatov et al. [13] and Jerman et al. [14]. The process produced several types of $\operatorname{Ti}(\mathrm{OH}) \mathrm{x}(4-\mathrm{x})^{+}$ hydroxocomplexes in equilibrium with $\mathrm{x}<4$. The value of $\mathrm{x}$ changed with reactant concentration, $\mathrm{pH}$, and temperature. When temperature was increased, particle size of $\mathrm{TiO}_{2}$ increased, leading to the formation of precipitate. Yoldas [15] has studied the gelatination process of titanium dioxide. The influence of reactant on hydrolysis and condensation was discussed. They discovered that when an alkyl, as the reactant, was increased, the hydrolytic reaction and the diffusion rate were both slowed down. As a result, the gelatination product formed was smaller, which contained lower concentration of oxide compound.

The addition of some acidic compounds, such as $\mathrm{HCl}$, $\mathrm{HNO}_{3}$, and $\mathrm{CH}_{3} \mathrm{COOH}$ in $\mathrm{Si}(\mathrm{OR})_{4}$, may be used to control the speed of hydrolysis [16]. Some literature on solar cells [17-20] has mentioned the ideal nanocrystal sizes, ranging 
TABLE 1: Comparison of different preparation methods for titanium dioxide nanoparticle colloidal paste from $\mathrm{TiCl}_{4}$.

\begin{tabular}{|c|c|c|c|c|c|c|}
\hline Sample & Hardness & BET surface area $\left(\mathrm{m}^{2} / \mathrm{g}\right)$ & Pore diameter $(\AA)$ & Pore volume $\left(\mathrm{cm}^{3} / \mathrm{g}\right)$ & $d_{\mathrm{BET}}$ & $d_{\mathrm{SEM}}$ \\
\hline P25 & $\mathrm{HB} \sim \mathrm{F}$ & 51.69 & 104.71 & 0.17 & 29.1 & - \\
\hline ETIP-TiO $_{2}$ & $6 \mathrm{H}$ & 60.54 & 129.29 & 0.19 & 24.8 & 28 \\
\hline H-ETIP-TiO 2 & $\mathrm{HB}$ & 52.78 & 74.32 & 0.13 & 28.4 & 45 \\
\hline TTIP-TiO $_{2}$ & $\mathrm{H}$ & 71.40 & 136.92 & 0.21 & 21.0 & 30 \\
\hline H-TTIP-TiO 2 & F & 72.05 & 232.01 & 0.13 & 20.8 & 30 \\
\hline $\mathrm{TiCl}_{4}-\mathrm{TiO}_{2}$ & $\mathrm{HB}$ & 83.10 & 125.49 & 0.26 & - & 105 \\
\hline
\end{tabular}

from 10 to $25 \mathrm{~nm}$, in achieving high cell efficiency. During the preparation of $\mathrm{TiO}_{2}$ powder, primary single-crystal particles may agglomerate to form secondary polycrystalline particles of various sizes, and such process is dependent on the synthesis routes. Shen et al. [21] had conducted a series of studies on the optical absorption and electron transfer of $\mathrm{TiO}_{2}$ with different particle and pore sizes. $\mathrm{TiO}_{2}$ powder with large pores as well as small particle sizes seemed to show high efficiency.

The dye adsorption and charge transport of $\mathrm{TiO}_{2}$ nanoparticle thin film coated with a substrate (e.g., ITO-or FTOcoated glass) have been studied extensively in recent years. The transport of photogenerated electrons or efficiency of device will be dependent on the adhesion of $\mathrm{TiO}_{2}$ thin film. In this study, pencil hardness technique was adopted to test the adhesion of $\mathrm{TiO}_{2}$ film prepared. Furthermore, nanocrystallites will beneficially influence the photocatalytic properties of $\mathrm{TiO}_{2}$ film by increasing the number of active sites, which reduces the risks of charge carrier recombination. In order to efficiently separate and collect photogenerated electrons and holes, $\mathrm{TiO}_{2}$ thin film must offer an environment that has high electron-transferring rate and less carrier traps. According to the results of recent studies on dye-sensitized solar cell, metal oxide is the main constituent for making the thin film. Among the various metal oxides, titanium dioxide is most often selected [22, 23].

Here, three types of precursors were used in the solgel method to prepare $\mathrm{TiO}_{2}$ working photoelectrode. The purpose is to control the film thickness and produce a mesoporous $\mathrm{TiO}_{2}$ film. The previously reported mesoporous films were only few micrometers thick. Such thin films provide insufficient surface areas for dye adsorption. On the other hand, a thick film with large BET surface areas will harvest more light, which translates to higher efficiency. The $\mathrm{TiO}_{2}$ film prepared in this study was sensitized by commercial $\mathrm{N}_{3}$ dye and was applied as the photoelectrode in dye-sensitized solar cell.

\section{Experimental}

2.1. Materials. P-25 $\mathrm{TiO}_{2}$ (70\% anatase, $30 \%$ rutile, primary particle size $30 \mathrm{~nm}$, Degussa) powder purchased from Aldrich was used for comparison purpose. Titanium(IV) isopropoxide (TTIP, 97\%, Aldrich), titanium(IV) ethoxide (TTIE, ACROS), and titanium tetrachloride ( $\left.\mathrm{TiCl}_{4}, \mathrm{Merck}\right)$ were precursors for preparing titanium dioxide by sol-gel method. The adjustment of $\mathrm{pH}$ was done by adding reagent grade $\mathrm{NaOH}$ (Merck). Triton X-100 (Merck) and polyethylene glycol (PEG M.W = 20,000, Fluka) were used as binders, and N3 dye (Ruthenium 533 bis-TBA, Solaronix) was used as the sensitizer. The R150 redox electrolyte was purchased from the Solaronix Commercials. Acetic acid and ethanol were purchased from Merck. All other solvents and reagents were analytical-grade quality, purchased commercially, and used without any further purification.

ITO-conducting glass $\left(20 \sim 30 \Omega / \mathrm{cm}^{2}\right.$, Merck, Co., ltd.) was selected as the substrate for $\mathrm{TiO}_{2}$ film. Wolff-wilborn hardness pencil test was adopted for the $\mathrm{TiO}_{2}$ film adhesion test. The crystalline property of $\mathrm{TiO}_{2}$ film was modified using the hydrothermal method with a bomb-type autoclave. In order to avoid the contamination of colloidal paste and protect the autoclave, a teflon beaker was lined in the stainless steel bomb.

\subsection{Preparation Methods and Measurement}

2.2.1. Sol-Gel and Hydrothermal Preparation Methods. A series of $\mathrm{TiO}_{2}$ nanoparticles were prepared by sol-gel method using acetic acid and nitric acid as the catalytic agent. The sol-gel was prepared from three precursors including titanium(IV) isopropoxide (TTIP), titanium(IV) ethoxide (TTIE), and titanium tetrachloride $\left(\mathrm{TiCl}_{4}\right)$. The solvent used was ethanol to give a solvent/precursor molar ratio of $1 / 1$. High-purity helium (99.99\%) was flowed through the reactor. This solution was added dropwise to the mixture containing 5.2 moles of acetic acid and 50 moles of DI water (deionized water) cooled at $5^{\circ} \mathrm{C}$ under helium gas purging and vigorous stirring. In order to increase the stability of TTIP and control the particle size [24], the sol-gel was prepared at $5^{\circ} \mathrm{C}$ under helium gas purge. Fresh sol-gel solution was transparent without any precipitate. After hydrolysis and condensation, the mixture was heated at $80^{\circ} \mathrm{C}$ in a water bath for $8 \mathrm{~h}$. After that, the temperature was gradually decreased to room temperature. The resulting sol-gel was placed into an autoclave to undergo the hydrothermal process, which heated the mixture at $190^{\circ} \mathrm{C}$ for $12 \mathrm{~h}$. After hydrothermal process, the mixture became thick and concentrated. $\mathrm{TiO}_{2}$ catalysts prepared were denoted as $\mathrm{Y}-\mathrm{TiO}_{2}$, where $\mathrm{Y}$ represents the precursor of titanium added. To further study the effect of acid used during hydrolysis, acetic acid was replaced by $\mathrm{HNO}_{3}$, and the catalysts prepared were denoted as X-Y$\mathrm{TiO}_{2}$. The preparation conditions of $\mathrm{TiO}_{2}$ photocatalysts are listed in Table 1. 
2.2.2. Characterization. The mesoporous $\mathrm{TiO}_{2}$ thin film was characterized by nitrogen sorption, Nano-ZS, XRD, SEM, and UV-vis. The efficiencies of photoelectrodes fabricated by these $\mathrm{TiO}_{2}$ thin films were also tested with a solar simulator.

Particle size distribution of the colloidal paste was measured by a nanoparticle analyzer (Malvern zetasizer NanoZS).

Powder X-ray diffraction (XRD) measurements were taken using a Bruker-D8-ADVANCE powder diffractometer with $\mathrm{Cu}-\mathrm{K} \alpha$ radiation $(40 \mathrm{kV}, 30 \mathrm{~mA})$. The sample was scanned over the $2 \theta$ range of $20-60^{\circ}$ at a rate of $0.05^{\circ} \mathrm{min}^{-1}$ to identify the crystalline structure. Sample for XRD was prepared as a thin layer on a sample holder.

BET surface areas were obtained by physisorption of nitrogen at $-197^{\circ} \mathrm{C}$ using a micromeritics ASAP-2020 instrument. Prior to measurement, the samples were degassed to $0.1 \mathrm{~Pa}$ at $100^{\circ} \mathrm{C}$. The surface areas were calculated in a relative pressure range $0.05<p / p_{o}<0.2$ assuming a crosssectional area of $0.162 \mathrm{~nm}^{2}$ for the $\mathrm{N}_{2}$ molecules.

Scanning electron microscopy (SEM) images were obtained with a Hitachi 4800 field emission microscope using an acceleration voltage of $20 \mathrm{kV}$. Samples were placed on a stage especially made for SEM. They were coated with Pt prior to analysis and imaged directly. SEM images were recorded at magnification that ranged from $50000 \mathrm{X}$ to $110000 \mathrm{X}$. The magnification was calibrated in pixel/nm on the camera. The chemical composition of the sample was determined by scanning electron microscopy-X-ray energydispersive spectrum (SEM-EDS) with accelerating voltage of $20 \mathrm{kV}$.

The diffuse reflectance UV-vis spectra were measured with a UV 3101PC UV-visible spectrophotometer. Powder samples were loaded in a quartz cell with suprasil windows, and spectra were collected in the range from $300 \mathrm{~nm}$ to $800 \mathrm{~nm}$ against quartz standard.

2.2.3. Preparation and Analysis of Mesoporous Titania Film Working Photoelectrode. Dye-sensitized solar cell prepared was consisted of a $\mathrm{TiO}_{2}$ working electrode coated with ITO conducting glass, a counter electrode, and electrolyte dispersed in between. $\mathrm{TiO}_{2}$ film working electrodes prepared from different titanium precursors (e.g., TTIP- $\mathrm{TiO}_{2}$, TTIE$\mathrm{TiO}_{2}$, and $\left.\mathrm{TiCl}_{4}-\mathrm{TiO}_{2}\right)$ were coated on ITO glass $(20 \mathrm{~mm} \times$ $10 \mathrm{~mm}$ ) by doctor-blade method [25]. The thickness of $\mathrm{TiO}_{2}$ film after calcination was measured by Tencor $\alpha$-step profiler, which gave more reliable results than those in previous report [26]. The size and thickness of solar cell were controlled by $3 \mathrm{M}$ tape. The area of photoelectrode was about $0.25 \mathrm{~cm}^{2}$ $(0.5 \mathrm{~cm} \times 0.5 \mathrm{~cm})$, and the thickness was about $15 \mu \mathrm{m}$ before calcination. The $\mathrm{N}_{3}$ dye was adsorbed onto the working electrode by soaking $\mathrm{TiO}_{2}$ film in $0.2 \mathrm{M}$ dye solution using ethanol as the solvent. The amount of $\mathrm{N}_{3}$ dye adsorbed on $\mathrm{TiO}_{2}$ film was determined by UV-vis spectrophotometer, where the chemisorbed dye on $\mathrm{TiO}_{2}$ film was desorbed by adding a mixture of $\mathrm{NaOH}$ and ethanol $(1: 1)$, and the resulting solution was measured.

Counter electrode was made by sputtering a layer of platinum on ITO glass. The photovoltaic property of the cell

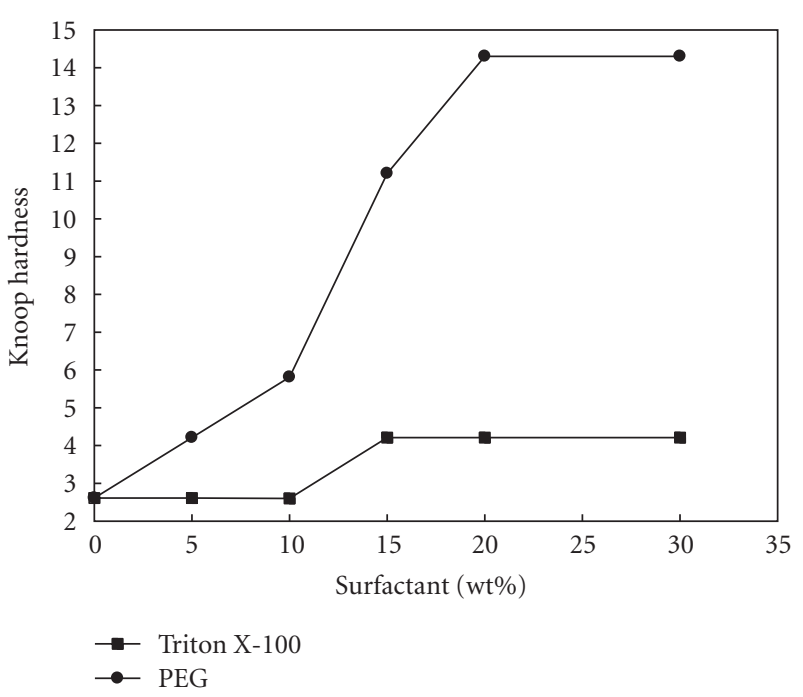

FIGURE 1: Effect of surfactant addition on the P25 thin film hardness.

was measured by solar simulator (i.e., AM 1.5, $100 \mathrm{~mW} / \mathrm{cm}^{2}$, YAMASHITA YSS-80A). The light intensity of solar simulator was calibrated by standard silicon solar cell $(223 \mathrm{mV})$.

\section{Results and Discussion}

3.1. Structural and Morphological Characteristics of $\mathrm{TiO}_{2}$ Thin Film. For dye-sensitized solar cell (DSSC), the adhesion of titania film on ITO glass is an important criterion that will impact the cell performance. This is because cracking of titania film tends to influence the interfacial transfer of charge carriers [27]. To prevent such phenomenon from happening, a surfactant such as PEG and triton X-100 was added to improve the adhesion of $\mathrm{TiO}_{2}$ thin film. In addition, PEG could also increase the thickness of $\mathrm{TiO}_{2}$ thin film and further enhance its light-absorbing ability $[28,29]$.

Figure 1 shows the effect of surfactant addition on the hardness of P25 thin film. From the figure, it is noted that $\mathrm{TiO}_{2}$ film with $20 \mathrm{wt} \%$ PEG demonstrated the best adhesion property. On the other hand, the addition of triton X-100 showed insignificant effect in improving the adhesion of $\mathrm{TiO}_{2}$ film. The formation of fine bubbles observed while mixing $\mathrm{TiO}_{2}$ paste with triton X-100 might be the reason for the poor adhesion.

Furthermore, adding surfactant has the effect of increasing the thickness of $\mathrm{TiO}_{2}$ film. This will prevent film cracking since thin film tends to crack more easily due to the shrinkage effect, that is, the change of $\mathrm{TiO}_{2}$ volume due to evaporation and decomposition of organic substances, which induces considerable stress on the film [30].

Since the alkoxide titanium will quickly react with water to generate titanium hydroxide, the reaction was kept at $5^{\circ} \mathrm{C}$ during hydrolysis and followed by the acidification reaction. The acidification reaction can enhance the crystalline property of the nanoparticle. The mixture at the moment was not considered a paste since the particle size and solvent constituent must be further conditioned by the hydrothermal 


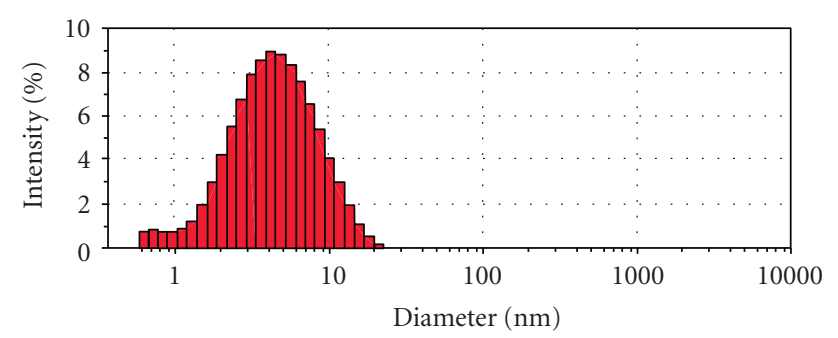

FIGURE 2: Colloidal nanoparticle size distribution before hydrothermal treatment.

treatment at a temperature of $190^{\circ} \mathrm{C}$. Dominant factors that will influence the characteristics of the thin film include particle size, particle morphology, and solvent constituent of the paste $[31,32]$. The experimental results show that TTIE- $\mathrm{TiO}_{2}$ colloidal paste with the controllable particle size from 1 to $10 \mathrm{~nm}$ can be obtained with good reproducibility. Figure 2 indicates the typical particle size distribution of TTIE- $\mathrm{TiO}_{2}$ sol-gel before hydrothermal treatment, which is similar to that of the original sol-gel colloidal solution. A mixture of alcohol and water is a suitable dispersion solution for measuring nanoparticle size distribution. Originally, the particle size of colloidal solution was below $10 \mathrm{~nm}$. However, both the particle size and the crystallinity of the colloid were increased after carrying out the hydrothermal treatment.

3.2. SEM. The SEM images in Figures 3, 4, 5, 6, and 7 show the average diameter of $\mathrm{TiO}_{2}$ particles, which is about 28,30 , 105, 30 and $45 \mathrm{~nm}$ for TTIE-TiO 2, TTIP-TiO, $\mathrm{TiCl}_{4}-\mathrm{TiO}_{2}$, $\mathrm{H}$-TTIP- $-\mathrm{TiO}_{2}$, and H-TTIE-TiO ${ }_{2}$, respectively. The BET surface area of P25 is $51.69 \mathrm{~m}^{2} / \mathrm{g}$. However, from the result of nitrogen adsorption-desorption isotherm, the prepared $\mathrm{TiO}_{2}$ paste showed higher surface area than that of commercial P25 powder.

The differences in morphology and particle size among the prepared $\mathrm{TiO}_{2}$ paste were observed by SEM. Nanoparticles of both TTIE- $\mathrm{TiO}_{2}$ and TTIP- $\mathrm{TiO}_{2}$ displayed spherical shape with apparent boundary. In contrast, nanoparticles of $\mathrm{TiCl}_{4}-\mathrm{TiO}_{2}$ had a rod-like shape. Obviously, differences in morphology or shape of the $\mathrm{TiO}_{2}$ nanoparticles prepared with different precursors and acids were observed. The porous structure of $\mathrm{TiO}_{2}$ film was clearly observed from the SEM images.

As shown in Table 1, the BET surface area of TTIP- $\mathrm{TiO}_{2}$ and TTIE- $\mathrm{TiO}_{2}$ is $71.4 \mathrm{~m}^{2} / \mathrm{g}$ and $60.54 \mathrm{~m}^{2} / \mathrm{g}$, respectively, whereas that of TTIP- $\mathrm{TiO}_{2}$ and TTIE- $\mathrm{TiO}_{2}$ prepared with $\mathrm{HNO}_{3}$ is $72.05 \mathrm{~m}^{2} / \mathrm{g}$ and $52.78 \mathrm{~m}^{2} / \mathrm{g}$, respectively. Assuming the particles are spherical and nonporous, the average particle size can be estimated by the following equation: $\bar{d}(n m)=\left(6 / S_{\mathrm{BET}} \rho\right) \times 10^{3}$, where $S_{\mathrm{BET}}$ is the surface area and $\rho$ is the density of a particle using the value of $4.0 \mathrm{~g} / \mathrm{cm}^{3}$ ( the density of titania). The average particle size calculated from BET surface area is $21 \mathrm{~nm}, 24.8 \mathrm{~nm}, 20.8 \mathrm{~nm}$, and $28.4 \mathrm{~nm}$ for TTIP-TiO 2 , TTIE-TiO 2 , H-TTIP-TiO 2 , and H-TTIE-TiO ${ }_{2}$, respectively. The results indicated that all particles are in nanoscale. It should be noted that the average particle size was overestimated because the catalyst under measurement

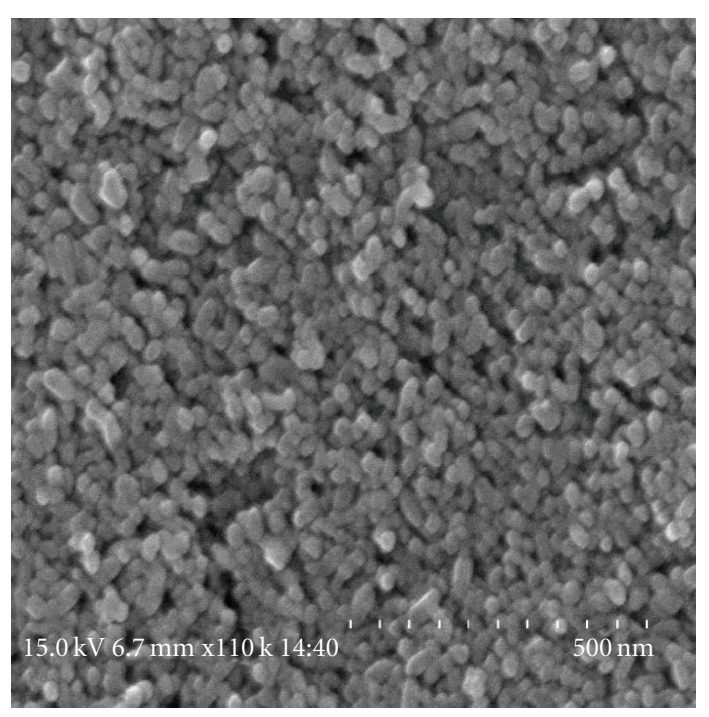

(a)

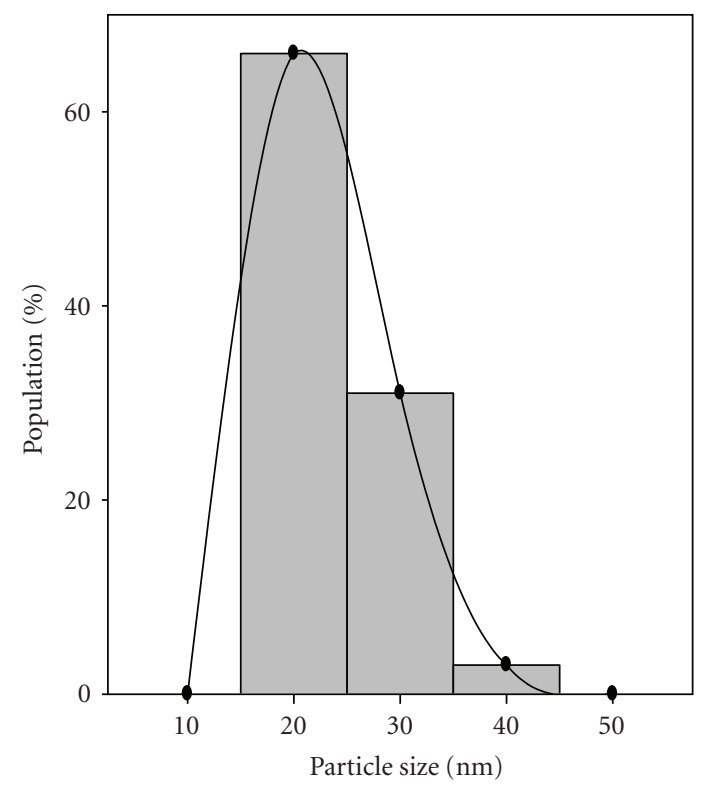

(b)

Figure 3: TTIE- $\mathrm{TiO}_{2}$ thin film morphology after annealing at $500^{\circ} \mathrm{C}$.

was pretreated at $120^{\circ} \mathrm{C}$ before nitrogen sorption, which could cause metal sintering to some extent.

3.3. XRD. All $\mathrm{TiO}_{2}$ films prepared in this study have nanosize particles. Figure 8 shows the XRD pattern of the $\mathrm{TiO}_{2}$ film that was coated on ITO glass by doctor blending followed by calcination at $500^{\circ} \mathrm{C}$ for $1 \mathrm{~h}$.

The XRD patterns of different samples prepared under temperature of $190^{\circ} \mathrm{C}$ are shown in Figure 8. Only anatase peaks at $2 \theta$ of around $25,38,48$, and $55^{\circ}$ were observed. Therefore, the selection of different precursor (TTIE and TTIP) for preparing $\mathrm{TiO}_{2}$ will not affect its crystalline structure. 


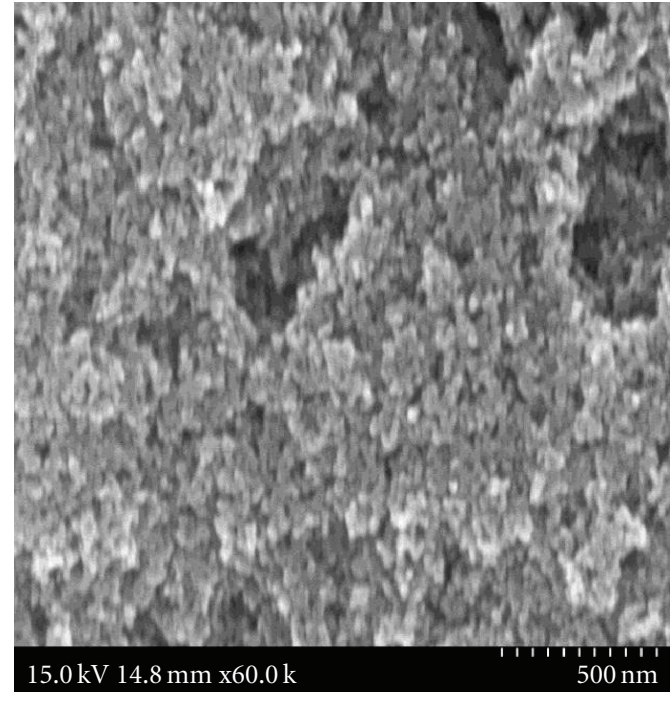

(a)

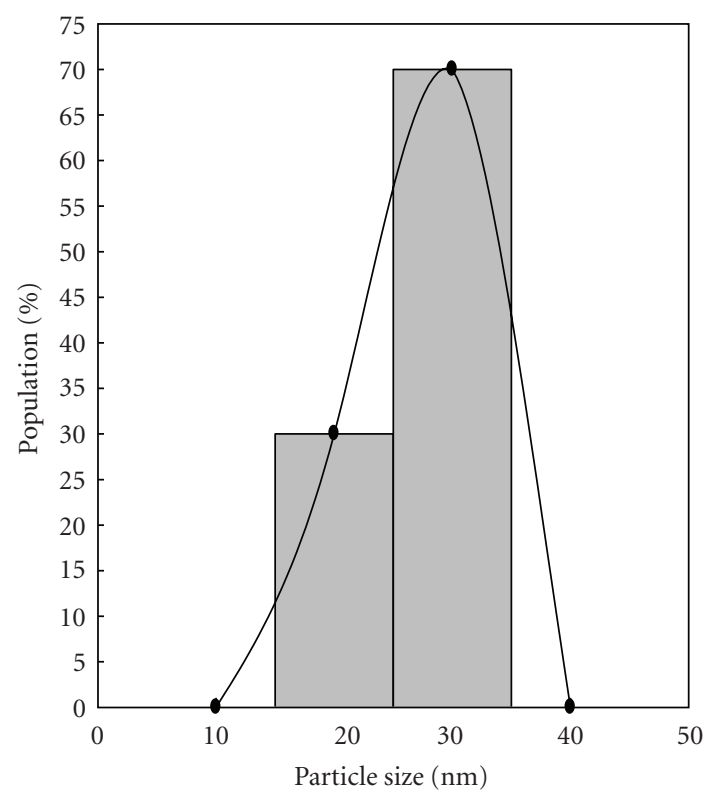

(b)

Figure 4: TTIP- $\mathrm{TiO}_{2}$ thin film morphology after annealing at $500^{\circ} \mathrm{C}$.

The XRD results show that TTIP-TiO 2 (500) and TTIE$\mathrm{TiO}_{2}$ (500) were composed of both anatase and rutile phases. The rutile phase was formed during high-temperature calcination at $500^{\circ} \mathrm{C}$. The main peaks of TTIP-TiO ${ }_{2}$ and TTIE$\mathrm{TiO}_{2}$ became sharper as the calcination temperature was increased, indicating an increase in its crystallinity. The XRD patterns of $\mathrm{TiCl}_{4}-\mathrm{TiO}_{2}$ (500) show both rutile and anatase phases; however, no change in peak sharpness has been observed. Nevertheless, the XRD patterns show that these $\mathrm{TiO}_{2}$ have the structure with short-range mesophase order, which is a typical characteristic of $\mathrm{TiO}_{2}$ [24].

3.4. Photoelectrode Characteristics. The photoconversion efficiency of solar cells fabricated from various $\mathrm{TiO}_{2}$ working

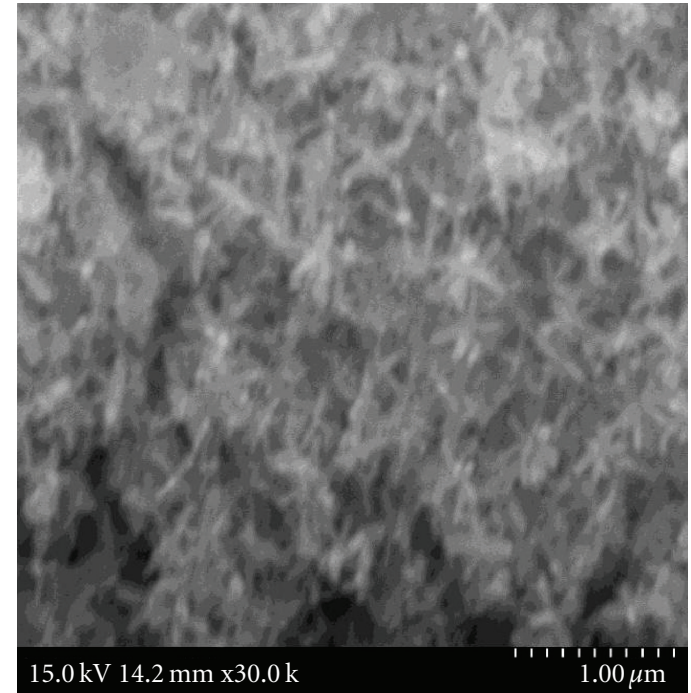

(a)

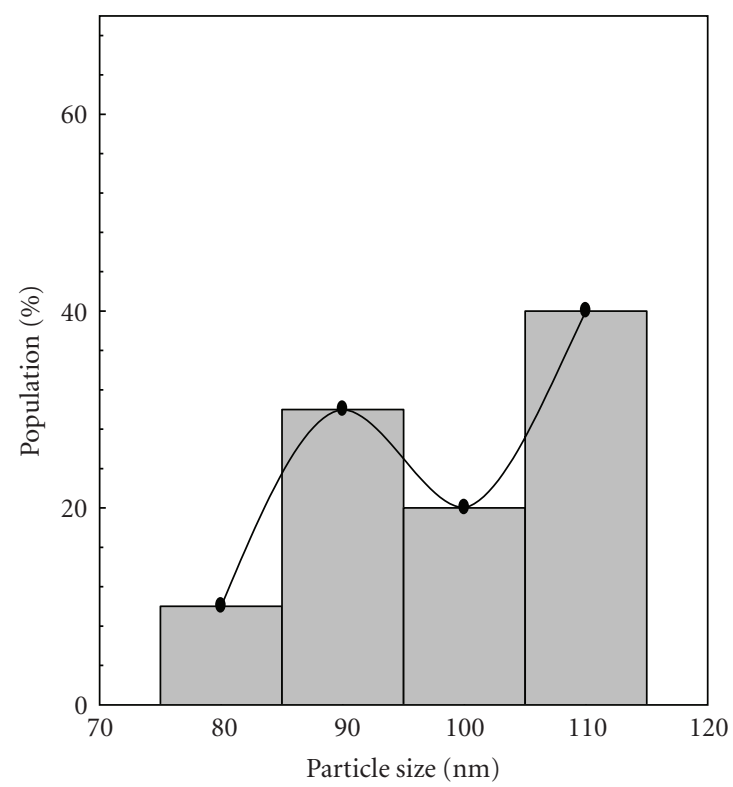

(b)

Figure 5: $\mathrm{TiCI}_{4}-\mathrm{TiO}_{2}$ thin film morphology after annealing at $500^{\circ} \mathrm{C}$.

electrodes were investigated in this study. The thickness of $\mathrm{TiO}_{2}$ film after calcination was estimated to be $8 \sim 9 \mathrm{~nm}$. The photocurrent generated by the solar cell is directly proportional to the amount of dye adsorbed on $\mathrm{TiO}_{2}$ film [19] which can be seen in Figure 9. It is noted that the amount of dye adsorbed on $\mathrm{TiO}_{2}$ increases with the film thickness. This is also in agreement with the increase in BET surface area as shown in Table 1.

The amount of dye chemisorbed on H-TTIP-TiO $\mathrm{H}_{2}$ film electrode was tested. Despite the fact that $\mathrm{H}$-TTIP-TiO 2 exhibited high surface area, its dye adsorption behavior was very poor. This can be explained by the small pore volume of $\mathrm{H}$-TTIP-TiO $2\left(0.13 \mathrm{~cm}^{3} / \mathrm{g}\right)$ as shown in Table 1 which limits its dye adsorption ability. 


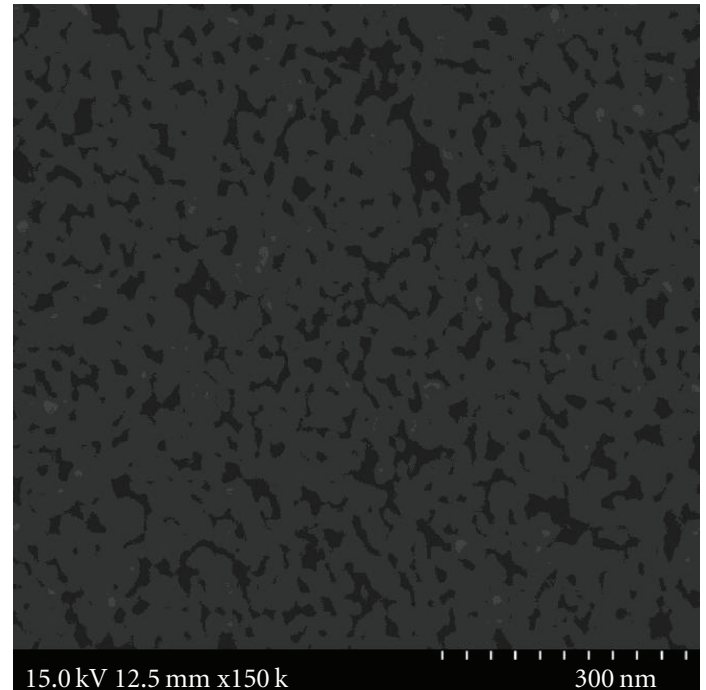

(a)

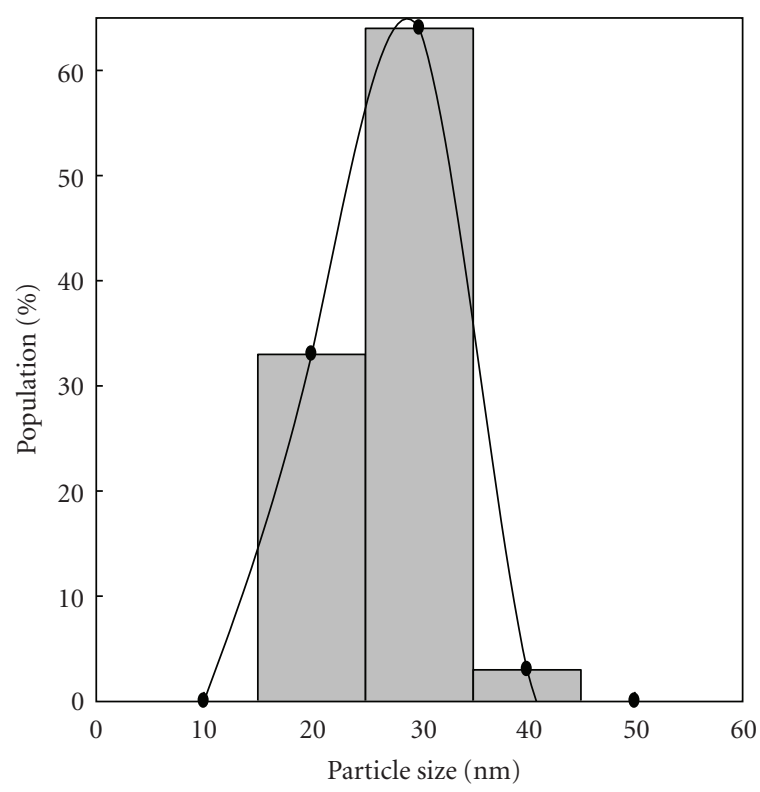

(b)

Figure 6: $\mathrm{H}-\mathrm{TTIP}-\mathrm{TiO}_{2}$ thin film morphology after annealing at $500^{\circ} \mathrm{C}$.

The H-TTIE-TiO 2 film prepared was composed mostly of spherical primary particles and some ellipse-like secondary particles. The use of TTIP precursor to react with different solvent and reactant will change the rate of hydrolysis and primary particle growth [33]. In other words, the primary and secondary particle size, surface morphology, composition, and porosity of $\mathrm{TiO}_{2}$ will be influenced by the concentration and type of precursor used.

Figure 10 shows photocurrent voltage characteristics of the cell made from various $\mathrm{TiO}_{2}$ calcined at $500^{\circ} \mathrm{C}$ for $0.5 \mathrm{~h}$. It is noted that the resistance of ITO conducting glass after calcination was increased to about $85 \sim 110 \Omega$. This will cause a big impact on the efficiency of the solar cell since ITO

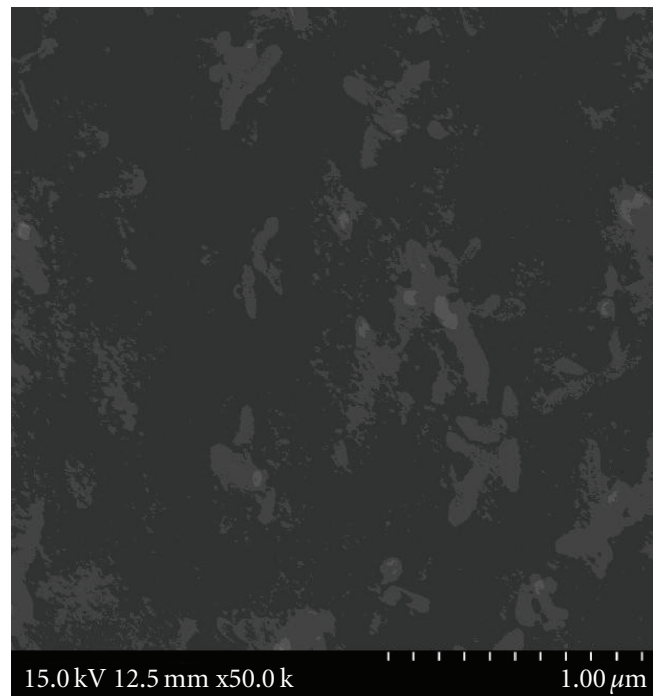

(a)

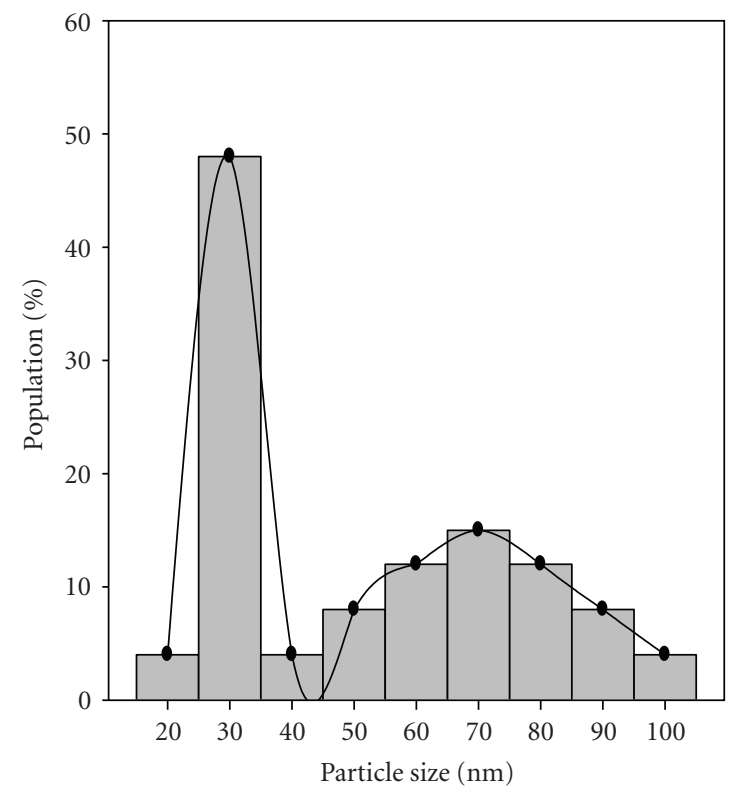

(b)

Figure 7: H-TTIE- $\mathrm{TiO}_{2}$ thin film morphology after annealing at $500^{\circ} \mathrm{C}$.

functions to transfer electrons that are photogenerated from dye-incorporated $\mathrm{TiO}_{2}$. From Table 2, it is obvious that the solar cell made from TTIP-TiO 2 thin film produces the largest short-circuit current (Jsc).

High photocurrent could be generally related to high surface area, which results in an increase in the amount of dye adsorbed if the film thickness and light irradiation intensity were kept constant. It might also be due to the presence of more anatase $\mathrm{TiO}_{2}$, which facilitates the electron transport [34]. This can be explained by the large pore size and high surface area of TTIP-TiO 2 electrode as revealed by SEM and BET analyses. In Tanaka's study, as the titania particle gets bigger, the chance of electron/hole recombination gets lower 
TABle 2: Performances of various $\mathrm{TiO}_{2}$ thin film electrodes for DSSC.

\begin{tabular}{|c|c|c|c|c|c|}
\hline Sample & Thickness $(\mu \mathrm{m})$ & $\mathrm{Jsc}\left(\mathrm{mA} / \mathrm{cm}^{2}\right)$ & $\operatorname{Voc}(\mathrm{V})$ & Fill factor & $\eta(\%)$ \\
\hline P25 & $10-11 \pm 0.5$ & 6.25 & 0.64 & 52.64 & 2.19 \\
\hline $\mathrm{TTIE} \mathrm{TiO}_{2}$ & $8-9 \pm 0.5$ & 5.63 & 0.70 & 62.18 & 2.45 \\
\hline $\mathrm{H}$-TTIE-TiO 2 & $8-9 \pm 0.5$ & 4.25 & 0.69 & 68.45 & 1.90 \\
\hline $\mathrm{TTIP} \mathrm{TiO}_{2}$ & $8-9 \pm 0.5$ & 13.13 & 0.76 & 44.96 & 4.45 \\
\hline H-TTIP-TiO ${ }_{2}$ & $8-9 \pm 0.5$ & 5.13 & 0.65 & 68.15 & 2.25 \\
\hline $\mathrm{TiCl}_{4}-\mathrm{TiO}_{2}$ & $8-9 \pm 0.5$ & 2.13 & 0.64 & 74.09 & 0.99 \\
\hline TTIP/TTIP* & $15-16 \pm 0.5$ & 15.50 & 0.67 & 57.89 & 6.03 \\
\hline
\end{tabular}

${ }^{*}$ Double layer of TTIP-TiO ${ }_{2}$ for efficiency test.

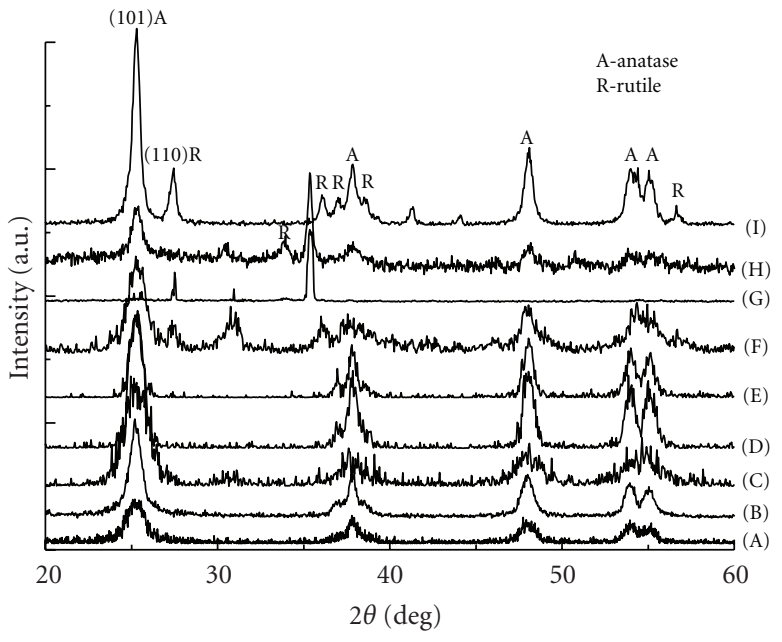

FIGURE 8: XRD patterns of $\mathrm{TiO}_{2}$ synthesized hydrothermally at $190^{\circ} \mathrm{C}$ for $12 \mathrm{~h}$ and calcinated at $500^{\circ} \mathrm{C}$ for $0.5 \mathrm{~h}$ (A: TTIP (190), B: TTIE (190), C: H-TTIP (190), D: TTIP (500), E: TTIE (500), F: H-TTIP (500), G: H-TTIE (500), H: $\mathrm{TiCl}_{4}$ (500), I: P25).

[35]. The cell performance depends on the thickness of the $\mathrm{TiO}_{2}$ film. Therefore, we have made a double-layer TTIP$\mathrm{TiO}_{2}$ thin film electrode that has a thickness of $16 \mu \mathrm{m}$ [4]. By incorporating this double-layer electrode into a solar cell, a photoconversion efficiency as high as $6.03 \%$ can be reached. The sufficient film thickness will create large pore size and enough space which allow more redox electrolyte to diffuse into the film.

$\mathrm{TiCl}_{4}-\mathrm{TiO}_{2}$ shows the highest surface area; however, its solar energy conversion efficiency is only $0.99 \%$ with low $\mathrm{Jsc}$ of $2.13 \mathrm{~mA} / \mathrm{cm}^{2}$. It is attributed to the poor adhesion of $\mathrm{TiO}_{2}$ on ITO glass observed. The $\mathrm{pH}$ of $\mathrm{TiCl}_{4}-\mathrm{TiO}_{2}$ paste is around $1 \sim 2$, which might cause a corrosion problem on ITO conducting glass. Furthermore, $\mathrm{TiCl}_{4}-\mathrm{TiO}_{2}$ film showed poor adhesion when immersed in the iodine electrolyte after calcination. Although $\mathrm{TiCl}_{4}-\mathrm{TiO}_{2}$ showed poor performance, it displayed nanotube-like structure. If the adhesion problem can be eliminated, low-cost and high-efficiency solar cell may be fabricated.

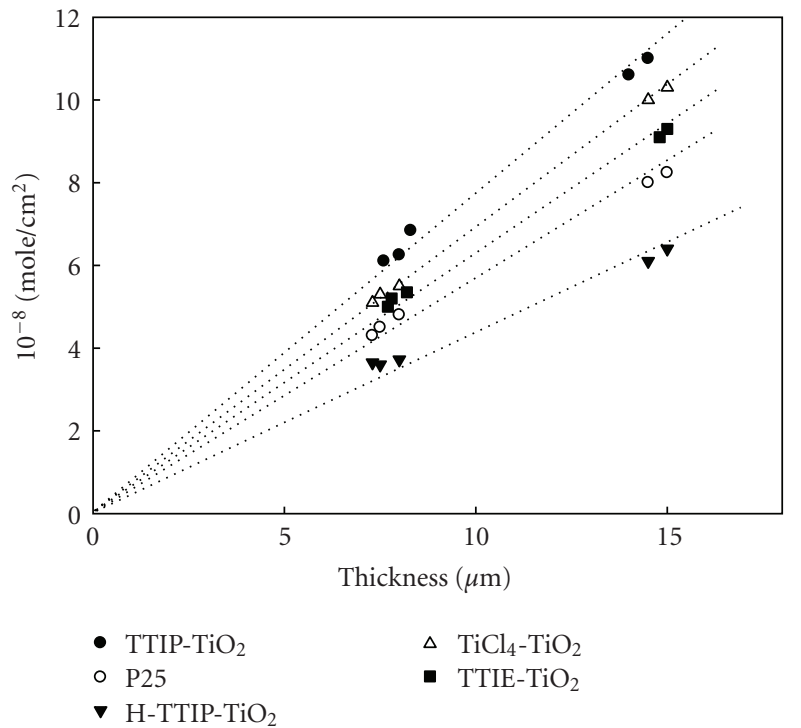

Figure 9: The amount of chemisorbed dye on the different thicknesses.

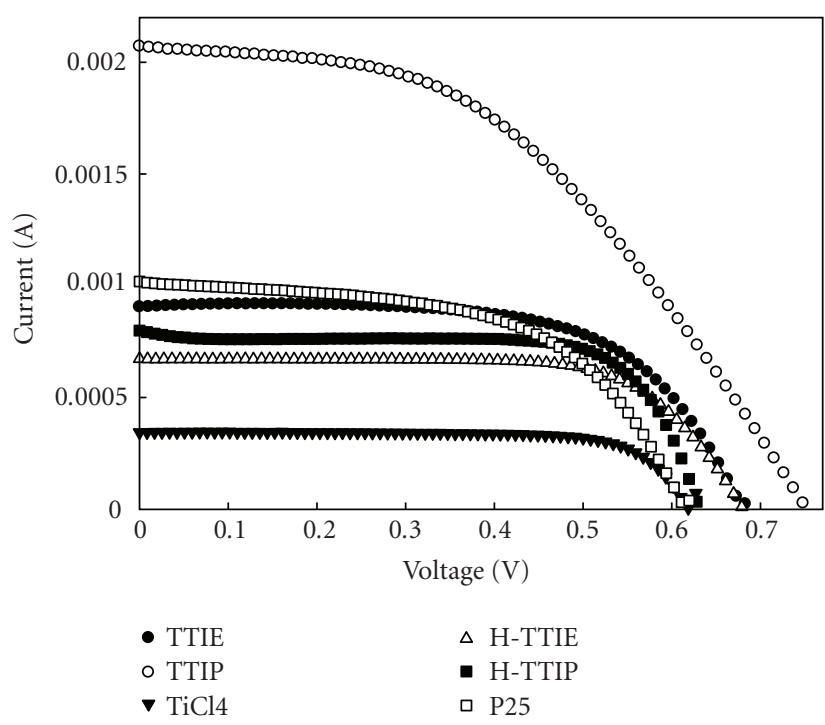

FIGURE 10: Photocurrent voltage characteristics of nanocrystalline $\mathrm{TiO}_{2}$ films prepared with different precursors. 


\section{Conclusion}

In this study, various $\mathrm{TiO}_{2}$ pastes were prepared with different precursors and acids. There are many factors that will influence the performance of DSSC, for instance, the nature of dye, semiconductor electrode, and activity of redox electrolyte, and so forth. In $\mathrm{DSSC} \mathrm{TiO}_{2}$ is the key component in determining the device efficiency. $\mathrm{TiO}_{2}$ prepared by solgel and hydrothermal method has the advantage of tuning its composition, particle size, and pore size distribution. The criteria of making an effective $\mathrm{TiO}_{2}$ working electrode include high surface area, appropriate band gap, and good adhesion [36]. $\mathrm{TiO}_{2}$ working electrode having high anatase content can facilitate electron transport due to its superior conductivity [34]. It is essential to increase the surface area of $\mathrm{TiO}_{2}$ nanoparticles in order to increase the amount of dye adsorbed. In this study, a double-layer TTIP-TiO $\mathrm{T}_{2}$ working electrode with a thickness of $16 \mu \mathrm{m}$ has been presented. The solar cell incorporating such double-layer working electrode has demonstrated a photoconversion efficiency as high as $6.03 \%$.

\section{References}

[1] L. Saadoun, J. A. Ayllon, J. Jimenez-Becerril, J. Peral, X. Domenech, and R. Rodriguez-Clemente, "Synthesis and photocatalytic activity of mesoporous anatase prepared from tetrabutylammonium-titania composites," Materials Research Bulletin, vol. 35, no. 2, pp. 193-202, 2000.

[2] B. O’Regan and M. Gratzel, "A low-cost, high-efficiency solar cell based on dye-sensitized colloidal TiO films," Nature, vol. 353, no. 6346, pp. 737-740, 1991.

[3] S. D. Burnside, V. Shklover, C. Barbé et al., "Self-organization of TiO nanoparticles in thin films," Chemistry of Materials, vol. 10, no. 9, pp. 2419-2425, 1998.

[4] M. K. Nazeeruddin, P. Péchy, T. Renouard et al., "Engineering of efficient panchromatic sensitizers for nanocrystalline TiObased solar cells," Journal of the American Chemical Society, vol. 123, no. 8, pp. 1613-1624, 2001.

[5] T. Yoko, A. Yuasa, K. Kamiya, and S. Sakka, "Sol-gel-derived TiO film semiconductor electrode for photocleavage of water. Preparation and effects of postheating treatment on the photoelectrochemical behavior," Journal of the Electrochemical Society, vol. 138, no. 8, pp. 2279-2285, 1991.

[6] K. A. Vorotilov, E. V. Orlova, and V. I. Petrovsky, "Sol-gel TiO films on silicon substrates," Thin Solid Films, vol. 207, no. 1-2, pp. 180-184, 1992.

[7] V. J. Nagpal, R. M. Davis, and S. B. Desu, "Novel thin films of titanium dioxide particles synthesized by a sol-gel process," Journal of Materials Research, vol. 10, no. 12, pp. 3068-3078, 1995.

[8] K. S. Yeung and Y. W. Lam, "A simple chemical vapour deposition method for depositing thin TiO films," Thin Solid Films, vol. 109, no. 2, pp. 169-178, 1983.

[9] J. -P. Lu, J. Wang, and R. Raj, "Solution precursor chemical vapor deposition of titanium oxide thin films," Thin Solid Films, vol. 204, no. 1, pp. L13-L17, 1991.

[10] S. Schiller, G. Beister, W. Sieber, G. Schirmer, and E. Hacker, "Influence of deposition parameters on the optical and structural properties of $\mathrm{TiO}$ films produced by reactive d.c. plasmatron sputtering," Thin Solid Films, vol. 83, no. 2, pp. 239-245, 1981.
[11] M. H. Suhail, G. M. Rao, and S. Mohan, "Dc reactive magnetron sputtering of titanium-structural and optical characterization of TiO films," Journal of Applied Physics, vol. 71, no. 3, pp. 1421-1427, 1992.

[12] K. Okimura, N. Maeda, and A. Shibata, "Characteristics of rutile TiO films prepared by r.f. magnetron sputtering at a low temperature," Thin Solid Films, vol. 281-282, no. 1-2, pp. 427430, 1996.

[13] Yu. D. Dolmatov, Zh. Priklad et al., "Changes of state of titanium (TV) during its hydrolysis in sulfuric acid," Zhurnal Prikladnoi Khimii, vol. 42, no. 8, pp. 1725-1732, 1969.

[14] Z. Jerman et al., "Gas/diffusion flow injection determination of ammonium ions in river and waste waters by conductometry," Collection of Czechoslovak Chemical Communications, vol. 31, no. 12, p. 3280, 1966.

[15] B. E. Yoldas, "Hydrolysis of titanium alkoxide and effects of hydrolytic polycondensation parameters," Journal of Materials Science, vol. 21, no. 3, pp. 1087-1092, 1986.

[16] K. Kamiya and S. Sakka, "Thermal expansion of $\mathrm{TiO}_{2} \mathrm{SiO}_{2}$ and $\mathrm{TiO}_{2} \mathrm{GeO}_{2}$ glasses," Journal of Non-Crystalline Solids, vol. 52, no. 1-3, pp. 357-363, 1982.

[17] Z. Zhang, C. C. Wang, R. Zakaria, and J. Y. Ying, "Role of particle size in nanocrystalline TiOi-based photocatalysts," Journal of Physical Chemistry B, vol. 102, no. 52, pp. 1087110878, 1998.

[18] A. J. Maira, K. L. Yeung, C. Y. Lee, P. L. Yue, and C. K. Chan, "Size effects in gas-phase photo-oxidation of trichloroethylene using nanometer-sized TiO catalysts," Journal of Catalysis, vol. 192, no. 1, pp. 185-196, 2000.

[19] S. Ito, S. Inoue, H. Kawada, M. Hara, M. Iwasaki, and H. Tada, "Low-temperature synthesis of nanometer-sized crystalline $\mathrm{TiO}$ particles and their photoinduced decomposition of formic acid," Journal of Colloid and Interface Science, vol. 216, no. 1, pp. 59-64, 1999.

[20] J. F. Porter, Y. G. Li, and C. K. Chan, "Effect of calcination on the microstructural characteristics and photoreactivity of degussa P-25 TiO," Journal of Materials Science, vol. 34, no. 7, pp. 1523-1531, 1999.

[21] Q. Shen, T. Toyoda et al., "Studies of optical absorption and electron transport in nanocrystalline TiO electrodes," Thin Solid Films, vol. 438-439, pp. 167-170, 2003.

[22] Y. Li, J. Hagen, W. Schaffrath, P. Otschik, and D. Haarer, "Titanium dioxide films for photovoltaic cells derived from a sol gel process," Solar Energy Materials and Solar Cells, vol. 56, no. 2, pp. 167-174, 1999.

[23] U. Diebold, “The surface science of titanium dioxide," Surface Science Reports, vol. 48, no. 5-8, pp. 53-229, 2003.

[24] Yu. Jiaguo, Yu. Huogen, B. Cheng, Z. Xiujian, and Z. Qingjie, "Preparation and photocatalytic activity of mesoporous anatase TiO nanofibers by a hydrothermal method," Journal of Photochemistry and Photobiology A: Chemistry, vol. 182, no. 2, pp. 121-127, 2006.

[25] A. A. Belhekar, S. V. Awate, and R. Anand, "Photocatalytic activity of titania modified mesoporous silica for pollution control," Catalysis Communications, vol. 3, no. 10, pp. 453$458,2002$.

[26] M. Adachi, I. Okada, S. Ngamsinlapasathian, Y. Murata, and S. Yoshikawa, "Dye-sensitized solar cells using semiconductor thin film composed of ceramic nanotubes," Electrochemistry, vol. 70, pp. 449-452, 2002.

[27] S. Ngamsinlapasathian, S. Sakulkhaemaruethai, S. Pavasupree et al., "Highly efficient dye-sensitized solar cell using 
nanocrystalline titania containing nanotube structure," Journal of Photochemistry and Photobiology A, vol. 164, no. 1-3, pp. 145-151, 2004.

[28] K. Srikanth, M. M. Rahman, H. Tanaka et al., "Investigation of the effect of sol processing parameters on the photoelectrical properties of dye-sensitized $\mathrm{TiO}_{2}$ solar cells," Solar Energy Materials and Solar Cells, vol. 65, no. 1, pp. 171-177, 2001.

[29] E. Stathatos, P. Lianos, and C. Krontiras, "Dye-sensitized photoelectrochemical cell using a nanocomposite $\mathrm{SiO}_{2} / \mathrm{Poiy}(\mathrm{eth}-$ ylene glycol) thin film as electrolyte support. Characterization by time-resolved luminescence and conductivity measurements," Journal of Physical Chemistry B, vol. 105, no. 17, pp. 3486-3492, 2001.

[30] K. Kajihara and T. Yao, "Macroporous morphology of the titania films prepared by a sol-gel dip-coating method from the system containing poly(ethylene glycol). IV. general principle of morphology formation and effect of heat treatment," Journal of Sol-Gel Science and Technology, vol. 17, no. 2, pp. 173-184, 2000.

[31] M. Wu, G. Lin, D. Chen et al., "Sol-hydrothermal synthesis and hydrothermally structural evolution of nanocrystal titanium dioxide," Chemistry of Materials, vol. 14, no. 5, pp. 1974-1980, 2002.

[32] A. Tolvanen, M.S. thesis, Helesinki University of Technology, Finland, 2003.

[33] C. Longo and M.-A. De Paoli, "Dye-sensitized solar cells: a successful combination of materials," Journal of the Brazilian Chemical Society, vol. 14, no. 6, pp. 889-901, 2003.

[34] N. G. Park, J. Van De Lagemaat, and A. J. Frank, "Comparison of dye-sensitized rutile-and anatase-based TiO solar cells," Journal of Physical Chemistry, vol. 104, no. 38, pp. 8989-8994, 2000.

[35] K. Tanaka, M. F. V. Capule, and T. Hisanaga, "Effect of crystallinity of $\mathrm{TiO}_{2}$ on its photocatalytic action," Chemical Physics Letters, vol. 187, no. 1-2, pp. 73-76, 1991.

[36] T. Ma, K. Inoue, H. Noma, K. Yao, and E. Abe, "Ionization potential studies of organic dye adsorbed onto $\mathrm{TiO}_{2}$ electrode," Journal of Materials Science Letters, vol. 21, no. 13, pp. 1013-1014, 2002. 


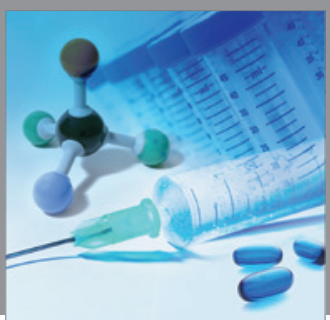

International Journal of

Medicinal Chemistry

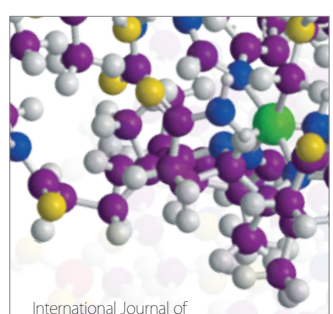

Carbohydrate Chemistry

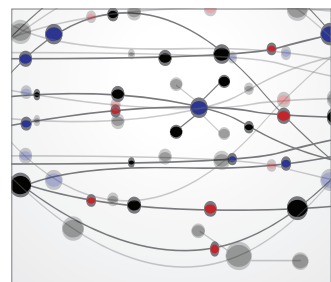

The Scientific World Journal
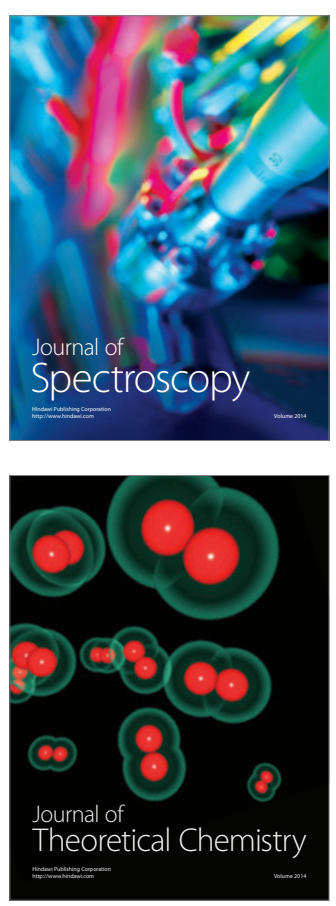
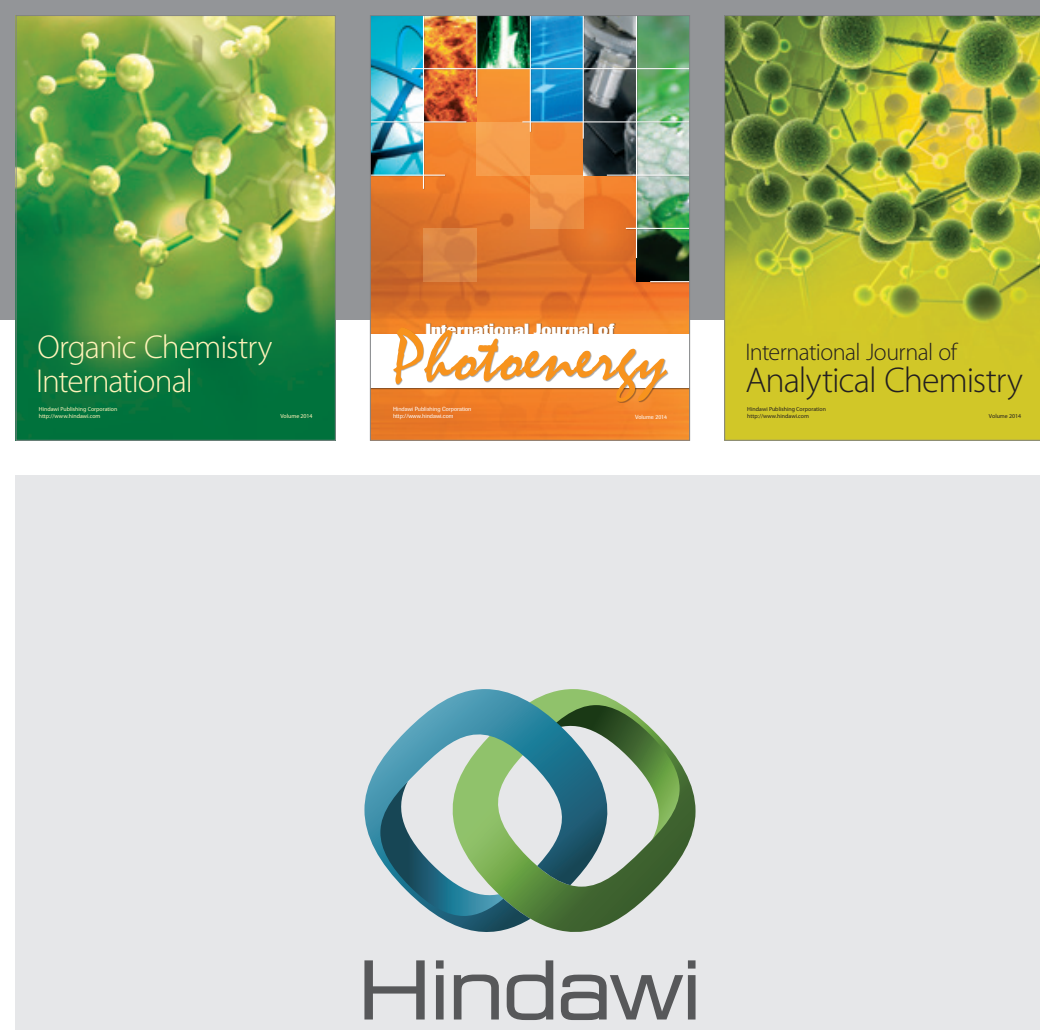

Submit your manuscripts at

http://www.hindawi.com
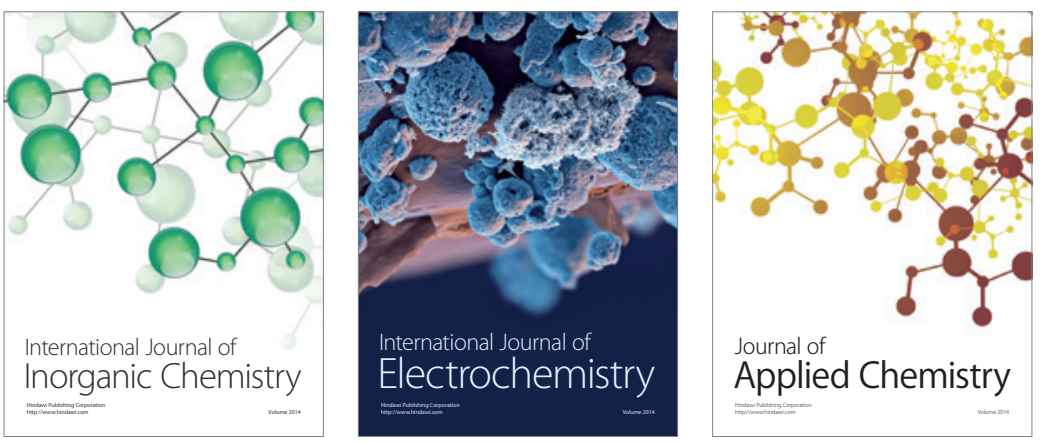

Journal of

Applied Chemistry
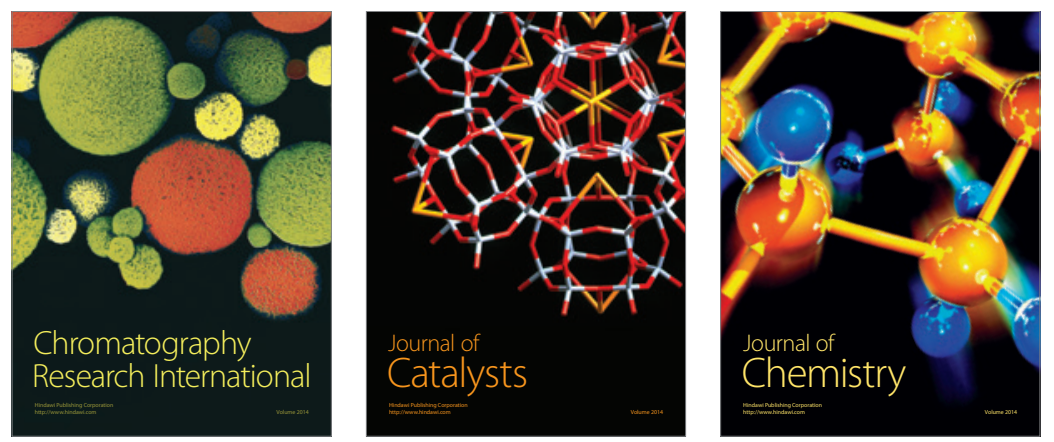
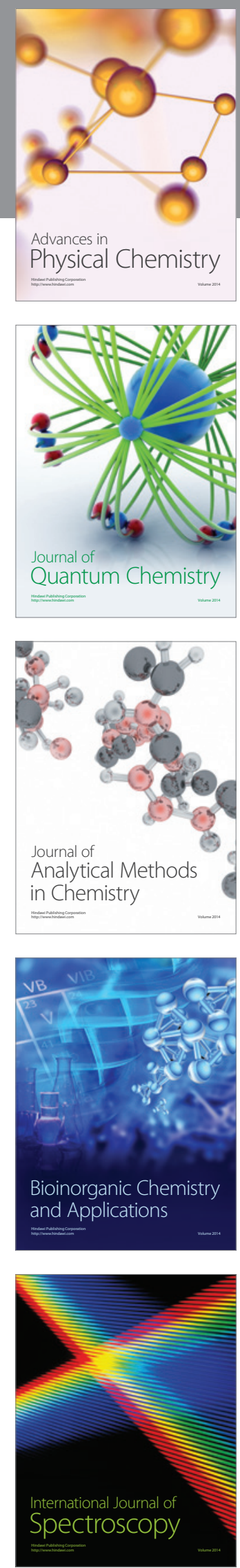